\title{
Influence of Different Rates of Irrigation to Olive Trees on Fruits Yield, Quality and Sensory Attributes of Olive Oil Output.
}

${ }^{1}$ Nahed M. M. Atta, ${ }^{1}$ Enaam Sh. A. Mohamed, ${ }^{1}$ Azza A. A. Ahmed and ${ }^{2}$ K.G. Gourgeose

${ }^{1}$ Fats and Oils Res. Dep., Food Tech. Research Institute, ${ }^{2}$ Horticulture Research Institute, ARC., Giza, Egypt.

Corresponding author:hatemhamdy888@yahoo.com

\begin{abstract}
An experiment was carried out in olive farm in Wady-El Natron, El Behera governorate, Egypt, to study the influence of deficit rate in different amounts of irrigation water, 96, 64 and 32 liter water / tree per hr.( at rates $80,53.3$ and $26.6 \%$, respectively) are given to olive trees (Coratina and Dolce vars.), and its compared with 120 liter water / tree per hr. (at rate 100\%) as a control on the chemical composition, promological parameters of olive fruits (fruit characteristics) and fruits yield and also on the quality parameters, fatty acids composition, natural antioxidant contents, stability and organoleptic characteristics (sensory attributes) of the extracted oils from olive fruits. The results showed that:-

The fruit characteristics of olive trees (Coratina and Dolce vars.) were affected by different amounts of irrigation water whereas, 100- fruit weight, fruit weight, pulp weight and pulp/stone ratio showed statistical variation at a significance level of 5\% according to the level of irrigation water applied, generally these parameters gradually decreased with lowering amount water during irrigation for two varieties. Values of FFA, $\mathrm{PV}, \mathrm{K} 232$, K270 and $\Delta \mathrm{k}$ of olive fruits oil decreased gradually by decreasing the amounts of irrigation water are given to olive trees in both two varieties. Oils from the 32 liter water / tree treatment had higher contents of oleic acid, total polyphenols and O-diphenol, higher oleic / linoleic and TUSFA / TSFA ratios and the highest oxidative stability, despite their lower total tocopherols, carotonids and chlorophyll contents compared with other treatments. Gradual reducing amount of irrigation water caused gradually an increase in fruitiness, bitterness and pungency in virgin olive oils in both two varieties.
\end{abstract}

Key words: Irrigation, olive trees, fruits yield, olive oil quality, O-diphenols and sensory attributes of olive oil.

\section{Introduction}

Olive (Olea europea L.) is drought- resistant and has traditionally been cultivated in areas with limited water resources in low density plantations under rainfed conditions. However, it responds positively to irrigation even with low amount of water (Moriana et al., 2003).

The chemical and organoleptic characteristics of olive oil depend on several factors (Salvador et al., 2001). According to Aparicio and Luna (2002), these factors are clustered into four main groups: environmental (soil, climate), cultivation (ripeness, harvesting), technological (fruit storage, extraction procedure), and agronomic factors (fertilization, irrigation). Among these factors irrigation is a major determinant of olive oil quality (Gomez-Rico et al., 2007).

Irrigated agriculture (AI) is shifting the paradigm of irrigation management from the full to partial supply of water needs. Nowadays, deficit irrigation (DI) is a common practice in many areas of the world, especially in dry regions. In these regions it can be more profitable for farmer to maximize crop water productivity than maximize the harvest per unit land (Ruiz-Sanchez et al., 2010).

Regulated deficit irrigation (RDI) improved water productivity, olive oil production, the organoleptic characteristics of the oil and the behavior of the fruits in olive mill (Alegre et al., 2002).
Many experiments have revealed reduction in vegetative growth induced by deficit irrigation (Moriana et al., 2003 and Iniesta et al., 2009). This effect, which is of great interest for controlling canopy size and for reducing the costs associated with specific agricultural practices, many reduce the number of fruits per tree.

In coming olive trees Goldhamer (1999) found that a reduction in water applied during mid summer of 15 to $25 \%$ of seasonal application for maximum yield did not have negative impacton yield.

Regulated deficit irrigation (RDI) is an appropriate method of irrigation for olive trees that does not necessarily have any negative impact on fruit or oil yield and quality if applied in the correct amount. RDI level of $65 \%$ produces the highest oil content and reaps water savings of $21 \%$ with no adverse effects on the quality of olive oil (Talozi and Alwaked, 2016).

Dabbou et al., (2010), in their experiment on olive tree in Tunisia, found that the best oil and fresh fruit production occurred with a $75 \%$ RDI scheme.

Ramos and Santos (2010), likewise found the highest oil and fruit yields occurring with a $60 \%$ sustaimed deficit irrigation regime within their olive tree test case in Portugal. The olive trees tested by Garcia et al., (2013) in Spain with RDI treatments saw higher oil yields and no difference in quality as compared to control cases.

Gomez-del-Campo (2013) reports that while the control treatment with no RDI on olive trees in Spain 
still had the highest oil content, one of the RDI treatments had an oil content very close to the control and just as importantly reaped significant water saving unlike the control group.

Togenetli et al. (2005) have recommended that RDI be applied to olive trees after the pit hardening stage to cover $66 \%$ of the crop evapotrans piration.

Oleic acid amount was found to be declined as the increase in water applied in irrigation regime (Berenguer et al., 2006, Gomez-Rico et al., 2007). Additional irrigation increased the palmitic and linoleic acid content and decreased oleic acid. Monounsaturated fatty acids /polyunsaturated fatty acids ratio was also decreased with irrigation supplements (Celil et al., 2009).

Total oil yield also varied with different water amounts and as the water increased about $75 \%$, highest total yield was attained due to increase in fruit number per tree (Motilva et al., 2000, d'Andria et al., 2004).

Gomez-Rico et al.(2007), working with the Manzanilla variety of olives, obtained a yield of $39.2 \mathrm{Kg}$ / tree from unirrigated trees and a maximum yield of $52.7 \mathrm{Kg} /$ tree from irrigated trees.

Intermediate irrigation treatments an olive oil chemical and sensory characteristics provided the best overall balance in oil quality and high oil production (Grattan et al., 2006, Berenguer et al., 2006).

Oil sensory properties of fruitiness, bitterness and pungency all declined in oils made from trees receiving more water. The lowest irrigation levels produced oil that were characterized by excessive bitterness very high pungency and woody, herbaceous flavors. Intermediate irrigation levels (33\% to $40 \%$ ETC) produced oils with balance complexity and characteristic artichoke, grass, green apple and some ripe fruit flavors. Higher irrigation levels lowered oil extractability and produced relatively bland oils with significantly less fruitiness and almost to bitterness pungency (Maria et al., 2006).

Table 1.Treatments of water applied for olive trees:-

\begin{tabular}{lccc}
\hline Olive trees of:- & $\begin{array}{c}\text { Irrigation treatments } \\
\text { (L. water / tree per hr.) }\end{array}$ & $\begin{array}{c}\text { Rates of } \\
\text { Irrigation }(\%)\end{array}$ & $\begin{array}{c}\text { Water Saving } \\
(\%)\end{array}$ \\
\hline \multirow{3}{*}{ Coratina } & 120 (control) & 100 & - \\
& 96 & 80 & 20 \\
& 64 & 53.3 & 46.7 \\
Dolce & 32 & 26.6 & 73.4 \\
& 120 (control) & 100 & - \\
\\
\end{tabular}

Yield values were not affected by the irrigation treatment. In contrast, 100-fruit weight, pulp ratio, moisture and oil content were affected by irrigation amounts. An increase in the amount of irrigation water given arise in moisture content and reduction in the oil content of olive fruit (Kaya et al., 2017).

Servili et al. (2007) showed that fully-irrigated trees of cv. Leccino yielded oils with a lower concentration of hydrophilic phenols and $\mathrm{O}$ diphenols than either the deficit-irrigated (about 50\% water of fully-irrigated trees) or complementaryirrigated ones.

The chemical components influenced by irrigation are the phenolic compounds, which affect both the oxidative stability and the sensory characteristics, especially the bitterness attribute (Gomez-Rico et al., 2007).

The aim of this investigation is to study the influence of different amounts of irrigation water on the yield and olive fruits characteristics and also on the quality of olive oil, to achieve a sustainable balance between water saving, yield fruits, oil production and oil quality.

\section{Materials and Methods}

Experimental olive farm: The study was carried out during the 2018 olive crop season in an experimental olive farm of Coratina and Dolce vars. (7 years old) olive trees planted at $6 \times 6 \mathrm{~m}$ and grown in sandy soil at the experimental farm was in Wady - El-Natron, El-Behera governorate, Egypt. Drip irrigation system was applied using underground water its salinity $1600 \mathrm{ppm}$. The experiment followed complete randomized block design, with 3 blocks pretreatment and three trees per plot for each varity.

Four treatments: were applied during season 2018 before commencement of this assay: 120, 96, 64 and 32 liter water/tree per hr.(Table 1) 120 liter water/tree per hr. was used as the control to compare the results obtained with the three irrigation treatments studied. The following table explain the vars.) in 2018 (from April to October) for different irrigation treatments (Table 2). total water applied to olive trees (Coratina and Dolce 
Table 2. Total water applied in period from April to October during season 2018 to both olive trees vars.:-

\begin{tabular}{llcccc}
\hline \multirow{2}{*}{ Months } & \multicolumn{1}{c}{ No. hours } & \multicolumn{3}{c}{ Total water applied of treatments in months (L. water / tree ) } \\
\cline { 3 - 5 } & & $\mathbf{1 2 0}$ & $\mathbf{9 6}$ & $\mathbf{6 4}$ & $\mathbf{3 2}$ \\
\hline April & $\mathbf{6} \mathbf{~ h r}$ / week & 2880 & 2304 & 1536 & 768 \\
May & $\mathbf{2}$ hr. daily/5days/week & 4800 & 3840 & 2560 & 1280 \\
June & $\mathbf{2}$ hr. daily/5days/week & 4800 & 3840 & 2560 & 1280 \\
July & $\mathbf{2}$ hr. daily & 7440 & 5952 & 3968 & 1984 \\
August & $\mathbf{2}$ hr. daily & 7440 & 5952 & 3968 & 1984 \\
September & $\mathbf{2}$ hr. daily/4 days/week & 3840 & 3072 & 2048 & 1024 \\
October & $\mathbf{2}$ hr. daily/4 days/week & 3840 & 3072 & 2048 & 1024 \\
\hline \multicolumn{2}{l}{ Total water applied (Liter/Tree) } & $\mathbf{3 5 0 4 0}$ & $\mathbf{2 8 0 3 2}$ & $\mathbf{1 8 6 8 8}$ & $\mathbf{9 3 4 4}$ \\
\hline
\end{tabular}

Fertilization :Fertilization was used to supply mineral before irrigation treatments were put into action, ammonium nitrate $(33 \%)$ with rat $2 \mathrm{Kg} /$ tree were divided into equal doses from April to September, potassium sulphat with rat $1 \mathrm{Kg}$ /tree/year divided into doses per 15 days, $1 / 2 \mathrm{Kg}$ phosphour / tree during winter fertilization on dose in trenches around the tree, it is added liter from sulphoric acid by exchanges with phosphoric acid once per month, the selected trees were sprayed three times/year with solution consist of boric acid plus urea $(\mathrm{N})$ plus calcium nitrate $(\mathrm{Ca})$ during flowering and fruits period.

Harvest olive fruits and oil extraction: Olive fruit samples from irrigation treatments trees were harvested throughout ripening, for each variety whereas Dolce variety harvested in mid October and Coratina var. in end October. Four representative samplings for each variety were gathered in 2018, the samples were collected by hand, then picked at each sampling and bring to the laboratory for oil extraction.

Yield: In order to determine the effect of different amounts irrigation water on yield each tree in the experimental was harvested separately then the olives obtained from each tree were weighed to determine the yield/tree (Kg/tree) (Kaya et al., 2017).

Promological parameters of olive fruits (fruit characteristics): Samples of 20 fruits from each replicate tree i.e. 60 fruits from each of the applied treatments were picked randomly at harvest to determine: Average fruit weight $(\mathrm{g})$, width $(\mathrm{cm})$, length $(\mathrm{cm})$ and pulp/seed ratio fruit were described by (Kaya et al., 2017).

Chemical composition of olive fruit: - Moisture, oil contents, crude protein, ash content and total carbohydrates were determined according to the methods of A.O.A.C (2000). But fiber content was estimated by difference.

Oil extraction: $5 \mathrm{Kg}$ fruits for each treatment olive trees of Coratina and Dolce cultivar were crushed and packed in cheese cloth then pressed using a laboratory hydraulic press. The pressure was 12.000 $\mathrm{Ib} / \mathrm{in}^{2}$ for $30 \mathrm{~min} /$ one which was reached gradually.
The extracted oil was dried over anhydrous sodium sulfate, through a what man filter paper No.1 and kept in brown glass bottles at $-5^{\circ} \mathrm{C}$ till their analysis.

Physiochemical properties of olive oils:-

- Refractive index of oils (RI), was determined at $25^{\circ} \mathrm{C}$ according to A.O.A.C. (2012) by using refractometer (NXRL-3 Poland).

- Free fatty acid as oleic acid \% (FFA) and peroxide values meq $\mathrm{O} 2 / \mathrm{kg}$ oil (PV) were determined according to the methods of the A.O.A.C. (2012).

- Absorbency in ultraviolet at 232 and $270 \mathrm{~nm}$. (K232 and K270): Ultraviolet and visible spectra were conducted using a pye unicum double beam recording spectrophotometer Model SP 1600, as described by Kates (1972). The oil samples were dissolved in freshly distilled cyclohexane and the absorption were measured at 232 and $270 \mathrm{~nm}$.

- $\Delta \mathrm{k}$ was calculated according to the method in the IOOC (2001) as the following equation:

$\Delta \mathrm{k}=\mathrm{A} 270-(\mathrm{A} 266+\mathrm{A} 274) / 2$

Determination of fatty acid composition: The fatty acids methyl esters were prepared using transestrification with cold methanolic solution of potassium hydroxide. The fatty acids methyl esters were identified by GC- capillary column according to the method of IOOC (2001).

\section{Determination of natural antioxidants in olive oils:-}

- Determination of total polyphenols was determined in olive oil samples according to the method of Gutfinger (1981).

- Determination of O-diphenols was determined in olive oil according to the method described by Mohamed and Sallanon (2006).

- Determination of total tocopherols was determined according to the method described by Wong et al. (1988).

- Determination of total pigments (chlorophyll and caroteniod contents): The chlorophyll and carotenoid contents of oil samples were determined according to the method of Mosquera et al. (1991).

- Oxidative stability (O.S) was evaluated by the Rancimat method (Mendez et al., 1997). Stability was expressed as the oxidation induction time (hours), measured with the Rancimat 679 apparatus 
(Metrohm Co., Switzerland), using 5g oil sample and heated to $100^{\circ} \mathrm{C}$ with air flow rate of $20 \mathrm{~L} / \mathrm{h}$.

Sensory attributes: The organoleptic assessment of virgin olive oil was conducted according to the method (profile sheet) described by IOC (2007).

Overall Quality Index (OQI):- The overall quality index (OQI) was introduced by the International Olive Oil Council (IOOC) to express virgin olive oil quality numerically (IOOC, 1990). This is a scale from 0 to 10 that considers four quality parameters: the score for sensory evaluation (SE), free acidity (FA), K270 and peroxide value (PV) according to the following equation:

$\mathrm{OQI}=2.55+0.91 \mathrm{SE}-0.78 \mathrm{FA}-7.35 \mathrm{~K} 270-0.066 \mathrm{PV}$.

Statistical analysis: All obtained data during season 2018 were subjected to analysis of variances according to using (CO/STAT). Least significant difference (L.S.D) was used to compare between means of treatments according to (Snedecor and Cochran, 1990) at probability of $5 \%$.

\section{Result and discussion}

The effect of different amounts of irrigation water on the yield:

Influence of different amounts of irrigation water applied to olive trees (Coratina and Dolce vars.) on fruits yield are shown in Table (3). There were differences in fruits yield among treatments during harvest year (2018). The lowest yield per tree was obtained as 11 and $23.1 \mathrm{Kg}$ from treatment 32 liter water/tree (per hr.) and the highest with 47 and 43.15 $\mathrm{Kg}$ was from treatment 120 liter water/tree (per hr.) for Coratina and Dolce vars., respectively.

Table 3. The effect of different amounts of irrigation on the yield:

\begin{tabular}{ccc}
\hline & \multicolumn{3}{c}{ Yield (Kg/tree) } \\
\cline { 2 - 3 } Treatments (L.water/tree per hr.) & Coratina & Dolce \\
\hline $\mathbf{1 2 0}$ & 47 & 43.15 \\
$\mathbf{9 6}$ & 43 & 39.9 \\
$\mathbf{6 4}$ & 22 & 33.9 \\
$\mathbf{3 2}$ & 11 & 23.1 \\
\hline
\end{tabular}

The promological parameters of olive fruits (fruit characteristics):

The values of fruit, pulp, stone weight (gm), pulp / stone ratio, fruit length, width $(\mathrm{cm})$ and fruit shape ratio(promological parameters) and 100- fruit weight obtained from olive trees (Coratina and Dolce vars.) showed statistical variation at a significance level of $5 \%$ according to the amounts of irrigation water applied (120, 96, 64 and 32 liter water / tree) in Tables 4 and 5, all previous parameters were affected by treatments and decreased as the amount of irrigation water decreased. This may be due to variation in total fruit load per tree Kaya et al., (2017).

\section{Chemical composition of olive fruits:}

The values of moisture, crude oil, protein, crude fiber, ash and total carbohydrates contents of fresh olive fruits from the olive trees Coratina and Dolce vars., irrigated with different amounts of irrigation water 96, 64 and 32 liter water / tree (per hr.) and compared there with $120 \mathrm{Lw} . /$ tree (control) are shown in Tables ( 6 and 7 ). From the tabulated data it could be noticed that, the previous values of chemical composition of fresh olive fruits were affected by the different deficit irrigation water, such that, as the amount water applied to olive trees (Coratina and Dolce vars.) decreased, the moisture, protein and fiber contents decreased in both two olive fruits, on the other hand, oil, ash and carbohydrate contents recorded gradually increased with decreasing amounts of irrigation water. The increase in oil content in olive fruits may be due to decrease in moisture content by reducing amount irrigation water and that meaning, this increase in oil content is relative increase.

Table 4. Effect of different amounts of irrigation on various promological parameters of Coratina olive fruits:

\begin{tabular}{lccccc}
\hline promological parameters & \multicolumn{3}{c}{ Irrigation treatments (L. water / tree per hr.) } & \multirow{2}{*}{ New L.S.D.(0.05) = } \\
\cline { 2 - 4 } & $\mathbf{1 2 0}$ & $\mathbf{9 6}$ & $\mathbf{6 4}$ & $\mathbf{3 2}$ & \\
\hline fruit weight (g) & 5.55 & 5.43 & 3.92 & 3.72 & 0.110 \\
pulp weight (g) & 4.47 & 4.35 & 3.09 & 2.92 & 0.119 \\
stone weight (g) & 1.08 & 1.08 & 0.83 & 0.80 & 0.028 \\
pulp /stone ratio & 4.14 & 4.01 & 3.72 & 3.65 & 0.221 \\
Fruit length (cm) & 2.76 & 2.65 & 2.33 & 2.09 & 0.018 \\
Width (cm) & 1.57 & 1.55 & 1.45 & 1.35 & 0.034 \\
fruit shape ratio & 1.76 & 1.71 & 1.61 & 1.54 & 0.049 \\
100-fruit weight (g) & 567.480 & 537.553 & 379.627 & 350.493 & 29.931 \\
\hline
\end{tabular}


Table 5. Effect of different amounts of irrigation on various promological parameters of Dolce olive fruits:

\begin{tabular}{lccccc}
\hline promological parameters & \multicolumn{3}{c}{ Irrigation treatments (L. water / tree per hr.) } & \multirow{2}{*}{ New L.S.D.(0.05) = } \\
\cline { 2 - 4 } & $\mathbf{1 2 0}$ & $\mathbf{9 6}$ & $\mathbf{6 4}$ & $\mathbf{3 2}$ & \\
\hline fruit weight (g) & 4.62 & 4.42 & 4.17 & 3.46 & 0.119 \\
pulp weight (g) & 3.75 & 3.58 & 3.35 & 2.72 & 0.041 \\
stone weight (g) & 0.87 & 0.84 & 0.82 & 0.74 & 0.037 \\
pulp /stone ratio & 4.31 & 4.26 & 4.09 & 3.67 & 0.398 \\
Fruit length (cm) & 3.16 & 3.03 & 2.90 & 2.08 & 0.039 \\
Width (cm) & 1.45 & 1.40 & 1.35 & 1.10 & 0.045 \\
fruit shape ratio & 2.18 & 2.16 & 2.14 & 1.89 & 0.276 \\
100-fruit weight (g) & 440.603 & 428.667 & 395.653 & 392.507 & 12.873 \\
\hline
\end{tabular}

Table 6. Effect of different amounts of irrigation on chemical composition of Coratina olive fruits (wet / weight):-

\begin{tabular}{lcccc}
\hline \multirow{2}{*}{ Chemical composition (\%) } & \multicolumn{3}{c}{ Irrigation treatments (L. water / tree per hr.) } \\
\cline { 2 - 5 } & $\mathbf{1 2 0}$ & $\mathbf{9 6}$ & $\mathbf{6 4}$ & $\mathbf{3 2}$ \\
\hline Moisture & 55.44 & 53.55 & 52.55 & 50.80 \\
Oil contents & 20.1 & 23.74 & 24.82 & 25.88 \\
Total protein & 3.06 & 2.25 & 1.86 & 1.86 \\
Crude fiber & 13.89 & 12.76 & 12.66 & 11.80 \\
Ash contents & 1.06 & 1.03 & 1.07 & 1.43 \\
Total carbohydrates & 6.45 & 6.67 & 7.30 & 8.23 \\
\hline
\end{tabular}

Table 7. Effect of different amounts of irrigation on chemical composition of Dolce olive fruits (wet / weight):-

\begin{tabular}{lcccc}
\hline Chemical composition (\%) & \multicolumn{4}{c}{ Irrigation treatments (L. water / tree per hr.) } \\
\cline { 2 - 5 } & $\mathbf{1 2 0}$ & $\mathbf{9 6}$ & $\mathbf{6 4}$ & $\mathbf{3 2}$ \\
\hline Moisture & 63.40 & 63.12 & 62.48 & 57.84 \\
Oil contents & 11.46 & 13.72 & 14.56 & 16.61 \\
Total protein & 2.47 & 1.71 & 1.62 & 1.70 \\
Crude fiber & 17.40 & 15.69 & 14.80 & 15.70 \\
Ash contents & 0.79 & 0.80 & 0.99 & 1.27 \\
Total carbohydrates & 4.48 & 4.96 & 5.55 & 6.88 \\
\hline
\end{tabular}

The physical and chemical characteristics of olive oils:-

Tables (8and 9) list the physical and chemical characteristics of olive oils (Coratina and Dolce vars.) as affected by the different irrigation treatments (96, 64 and 32 liter water / tree) and compared their with treatment (120 liter / tree) as a control. From the results in these tables, it could be noticed that, FFA, PV, K232 and 270, and $\Delta \mathrm{k}$ decreased as the degree of water deficit increased, but RI was non significantly different between irrigation treatments. The previous all parameters used to evaluate oil quality were only slightly affected by amounts of irrigation (96, 64 and 32 L.w/tree) except peroxide value recorded a higher decreased with decreasing amount water are given to olive trees in Coratina variety comparing with 120 L.w/tree (control). The noticed differences in these parameters of oil quality in both varieties may be due to different amount water of olive fruits that related to change in the activity of enzymes caused hydrolysis and oxidation for oils such as lipas and hydroperoxidase whose activity are more under higher content of moisture in fruits taken from trees irrigated with a higher amount water compared with trees received lower amount water under study. This indicated that, the positive effect of reducing amount irrigation water on the oil quality which important role played by reducing the values of FFA, PV and K232 and K270 nm. 
Table 8. Effect of different amounts of irrigation on physical and chemical properties of Coratina olive oils.

\begin{tabular}{|c|c|c|c|c|c|}
\hline \multirow{2}{*}{$\begin{array}{l}\text { Physical and chemical } \\
\text { properties }\end{array}$} & \multicolumn{4}{|c|}{ Irrigation treatments (L. water / tree per hr.) } & \multirow{2}{*}{$\begin{array}{c}\text { New L.S.D.(0.05) } \\
=\end{array}$} \\
\hline & 120 & 96 & 64 & 32 & \\
\hline RI at $25^{\circ} \mathrm{c}$ & 1.4675 & 1.4672 & 1.4672 & 1.4667 & N.S. \\
\hline FFA (as oleic acid \%) & 0.262 & 0.235 & 0.225 & 0.187 & 0.029 \\
\hline PV (meq O2 /kg oil) & 5.57 & 4.38 & 3.82 & 3.77 & 1.197 \\
\hline K232 nm. & 1.817 & 1.517 & 1.371 & 1.294 & 0.023 \\
\hline K270 nm. & 0.382 & 0.323 & 0.316 & 0.309 & 0.039 \\
\hline$\Delta \mathbf{k}$ & -0.006 & -0.006 & -0.007 & -0.008 & 0.002 \\
\hline
\end{tabular}

Table 9. Effect of different amounts of irrigation on physical and chemical properties of Dolce olive oils.

\begin{tabular}{lccccc}
\hline $\begin{array}{l}\text { Physical and chemical } \\
\text { properties }\end{array}$ & \multicolumn{2}{c}{ Irrigation treatments (L. water / tree per hr.) } & \multirow{2}{*}{$\begin{array}{c}\text { New L.S.D.(0.05) } \\
=\end{array}$} \\
\cline { 2 - 4 } RI at 25 ${ }^{\circ} \mathbf{c}$ & 1.4680 & 1.4679 & 1.4674 & 1.4671 & N.S. \\
FFA (as oleic acid \%) & 0.312 & 0.286 & 0.243 & 0.235 & 0.076 \\
& & & & & \\
PV (meq O2 /kg oil) & 5.72 & 5.68 & 5.53 & 5.39 & 0.041 \\
K232 nm. & 2.011 & 1.818 & 1.706 & 1.665 & 0.004 \\
K270 nm. & 0.368 & 0.339 & 0.309 & 0.302 & 0.033 \\
$\Delta \mathbf{~}$ & -0.005 & -0.007 & -0.008 & -0.008 & 0.002 \\
\hline
\end{tabular}

Fatty acid composition of olive oils:-

Data in Tables (10 and 11) illustrated, the fatty acid profile was analyzed in two olive oils varieties (Coratina and Dolce). In each variety there was a trend of increased oleic acid and reduced linoleic and linolenic acids contents with decreasing amount irrigation water. This trend for these major unsaturated fatty acids caused to increase monounsaturated fatty acid / polyunsaturated fatty acid ( MUFA / PUFA), total unsaturated fatty acids / total saturated fatty acids (TUFA/TSFA) and C18:1/ C18:2 ratios with reducing amounts of irrigation water. Also palmitic acid was decreased as a result of decreasing amounts of irrigation water. This indicated positive effect of reducing amount irrigation water on oil quality owing to the important role played by oleic acid in the health properties of olive oil (Bermudez et al., 2011).

Table 10. Effect of different amounts of irrigation on fatty acid composition of Coratina olive oils:-

\begin{tabular}{lccccc}
\hline \multicolumn{1}{c}{ Fatty acid } & \multicolumn{3}{c}{ Irrigation treatments (L. water / tree per hr.) } & New \\
\cline { 2 - 5 } composition (\%) & $\mathbf{1 2 0}$ & $\mathbf{9 6}$ & $\mathbf{6 4}$ & $\mathbf{3 2}$ & L.S.D.(0.05)= \\
\hline C16:0 & 14.99 & 14.88 & 13.35 & 12.95 & 0.913 \\
C16:1 & 0.66 & 0.64 & 0.62 & 0.61 & 0.021 \\
C17:0 & 0.04 & 0.04 & 0.04 & 0.04 & N.S \\
C17:1 & 0.05 & 0.06 & 0.06 & 0.06 & NS \\
C18:0 & 1.94 & 2.04 & 2.18 & 2.27 & 0.091 \\
C18:1 & 66.03 & 67.37 & 69.32 & 70.46 & 0.790 \\
C18:2 & 14.77 & 13.48 & 12.92 & 12.04 & 0.570 \\
C18:3 & 0.79 & 0.75 & 0.67 & 0.67 & 0.079 \\
C20:0 & 0.38 & 0.36 & 0.43 & 0.46 & 0.029 \\
C20:1 & 0.32 & 0.38 & 0.41 & 0.43 & 0.024 \\
T.Sat. & 17.38 & 17.32 & 16.00 & 15.72 & 0.761 \\
T.unsat. & 82.62 & 82.68 & 84.00 & 84.28 & 0.287 \\
Monunsat. & 67.06 & 68.45 & 70.41 & 71.57 & 0.734 \\
Polyunsat. & 15.56 & 14.23 & 13.59 & 12.71 & 0.647 \\
T.unsat/ T.sat. & 4.75 & 4.77 & 5.25 & 5.36 & 0.113 \\
Monunsat./polyuns. & 4.31 & 4.81 & 5.18 & 5.63 & 0.004 \\
C18:1/ C18:2 & 4.47 & 4.53 & 5.37 & 5.44 & 0.009 \\
\hline
\end{tabular}


Table 11. Effect of different amounts of irrigation on fatty acid composition of Dolce olive oils:-

\begin{tabular}{lccccc}
\hline \multicolumn{1}{c}{ Fatty acid } & \multicolumn{3}{c}{ Irrigation treatments (L. water / tree per hr.) } & \multicolumn{1}{c}{$\begin{array}{c}\text { New } \\
\text { L.S.D.(0.05)= }\end{array}$} \\
\cline { 2 - 5 } composition (\%) & $\mathbf{1 2 0}$ & $\mathbf{9 6}$ & $\mathbf{6 4}$ & $\mathbf{3 2}$ & 0.223 \\
C16:0 & 18.03 & 17.91 & 17.69 & 15.67 & 0.014 \\
C16:1 & 2.05 & 2.04 & 1.87 & 1.83 & N.S. \\
C17:0 & 0.05 & 0.05 & 0.05 & 0.05 & N.S. \\
C17:1 & 0.08 & 0.07 & 0.07 & 0.07 & 0.067 \\
C18:0 & 1.96 & 1.94 & 1.94 & 1.92 & 0.107 \\
C18:1 & 58.18 & 59.72 & 61.33 & 63.58 & 0.489 \\
C18:2 & 18.34 & 17.14 & 15.95 & 15.72 & 0.094 \\
C18:3 & 0.74 & 0.65 & 0.61 & 0.56 & 0.004 \\
C20:0 & 0.36 & 0.31 & 0.31 & 0.36 & 0.046 \\
C20:1 & 0.21 & 0.17 & 0.18 & 0.24 & 0.147 \\
T.Sat. & 20.40 & 20.21 & 19.99 & 18.00 & 0.969 \\
T.unsat. & 79.60 & 79.79 & 80.01 & 82.00 & 0.053 \\
Monunsat. & 60.52 & 62.00 & 63.45 & 65.72 & 0.347 \\
Polyunsat. & 19.08 & 17.79 & 16.56 & 16.28 & 0.271 \\
T.unsat/ T.sat. & 3.90 & 3.95 & 4.00 & 4.56 & 0.052 \\
Monunsat./polyuns. & 3.17 & 3.49 & 3.83 & 4.04 & 0.045 \\
C18:1/ C18:2 & 3.17 & 3.48 & 3.85 & 4.04 & \\
\hline
\end{tabular}

Natural antioxidants and stability of olive oils:

Tables (12 and 13) show the effect of amount of irrigation water (120, 96, 64 and 32 liter water / tree) on the natural antioxidants (total polyphenol, tocopherol, O-diphenol, carotenoid and chlorophyll contents) and stability of fruits oil obtained from olive trees ( Corotina and Dolce vars.). From the results, the amounts of these previous antioxidant compounds and stability of oils changed significantly according to the amounts of irrigation water given to each treatment. In both varieties the greatest amount from total phenols, $\mathrm{O}$ - diphenols and oxidative stability of oils were extracted from the lowest irrigation treatment. The stability was correlated very closely with total phenols content of the oil. Vice versa for total tocopherol, carotenoid and chlorophyll contents. The observed differences in polyphenols concentration in the olive oil could be a consequence of the different water stress level of olives that involve changes in the activity of enzymes responsible for phenolic compound synthesis, such as L-phenyl, alanine ammonia- lyase whose activity is greater under higher water stress conditions ( Gomez -Rico et al., 2007). And also the decreased in polyphenol contents of olive oil with increasing the amount of the water employed in the irrigation may be these compounds are mostly water soluble, it is not surprising that the water status of the tree and its fruit have an influence on the amount of polyphenols remaining in the oil after processing (Maria et al., 2006).

Table 12. Effect of different amounts of irrigation on natural antioxidants of Coratina olive oils:-

\begin{tabular}{lccccc}
\hline \multicolumn{1}{c}{$\begin{array}{c}\text { Natural antioxidants } \\
(\mathbf{p p m})\end{array}$} & \multicolumn{2}{c}{ Irrigation treatments $(\mathbf{L}$. water / tree per hr.) } & \multirow{2}{*}{ New L.S.D.(0.05) $=$} \\
\cline { 2 - 5 } & $\mathbf{1 2 0}$ & $\mathbf{9 6}$ & $\mathbf{6 4}$ & $\mathbf{3 2}$ & \\
\hline Total Polyphenols & 458.423 & 693.763 & 703.653 & 747.910 & 44.267 \\
O-diphenols & 76.673 & 94.307 & 105.410 & 147.570 & 42.169 \\
Total tocophenols & 242.603 & 226.453 & 222.373 & 205.660 & 16.159 \\
Carotenoid contents & 0.43 & 0.32 & 0.25 & 0.22 & 0.117 \\
Chlorophyll contents & 0.386 & 0.320 & 0.250 & 0.220 & 0.068 \\
Oxidative stability & 46.50 & 46.73 & 50.37 & 51.41 & 1.047 \\
$\quad\left(\right.$ hr.) at100 ${ }^{\circ} \mathbf{C}$ & & & & & \\
\hline
\end{tabular}

Table 13. Effect of different amounts of irrigation on natural antioxidants of Dolce olive oils:-

\begin{tabular}{lccccc}
\cline { 1 - 4 } \multicolumn{1}{c}{$\begin{array}{c}\text { Natural antioxidants } \\
\text { (ppm) }\end{array}$} & \multicolumn{2}{c}{ Irrigation treatments $(\mathbf{L}$. water / tree per hr.) } & New L.S.D.(0.05) \\
\cline { 2 - 5 } & $\mathbf{1 2 0}$ & $\mathbf{9 6}$ & $\mathbf{6 4}$ & $\mathbf{3 2}$ & \\
\hline Total Polyphenols & 131.510 & 224.540 & 405.493 & 434.353 & 31.692 \\
O-diphenols & 52.500 & 64.650 & 69.640 & 106.283 & 37.943 \\
Total tocophenols & 133.577 & 113.473 & 99.483 & 85.620 & 21.379 \\
Carotenoid contents & 0.520 & 0.330 & 0.250 & 0.207 & 0.203 \\
Chlorophyll contents & 0.987 & 0.650 & 0.280 & 0.120 & 0.339 \\
Oxidative stability & 21.44 & 21.47 & 24.33 & 25.68 & 2.671 \\
(hr.) at100 ${ }^{\circ} \mathbf{C}$ & & & & & \\
\hline
\end{tabular}


Sensory attributes of virgin olive oils:-

All the virgin olive oils obtained using the different amounts of irrigation treatments (120, 96, 64 and 32 liter water / tree) of the trees in both Coratina and Dolce vars. studied, were classified as extra virgin olive oil by mean of the organoleptic evaluation carried out by an IOOC (International olive oil council) recognized olive oil taster panel as shown in Tables (14 and 15).

Generally sensory attributes affected by different amounts of irrigation water were fruitiness, bitterness and pungency. With regarding the results in the previous Tables (14 and 15), intensity of fruitiness, bitterness and pungency were all higher in fruits oil obtained from trees treated with low amount irrigation water (32 liter water / tree), followed by irrigated with 64 liter water/tree, then trees treated with 96 liter water /tree compared with olive oils obtained from trees treated with 120 liter water / tree for two varieties. An increase in positive attributes especially pungency and bitterness related to higher phenol content in olive oils obtained from olive trees which treated with low amount water under study. Also Overall quality index (OQI) influenced by different amounts of irrigation water. The values of OQI for both Coratina and Dolce vars. recorded a higher increased with decreasing the amount of the water employed in irrigation. This increased in OQI by decreasing amounts of irrigation water for olive tree may be due to reduce in values of FFA, PV, $\mathrm{K}_{270}$ and increased the fruitiness in two both olive oils by decreasing irrigation amount water, whereas OQI calculated from four previous parameters (FFA, PV, $\mathrm{K}_{270}$ and fruitiness) .

Table 14. Effect of different amounts of irrigation on sensory attributes of Coratina virgin olive oils:-

\begin{tabular}{ccccc}
\hline & \multicolumn{4}{c}{ Irrigation treatments (L. water / tree per hr.) } \\
\cline { 2 - 5 } Sensory attributes & $\mathbf{1 2 0}$ & $\mathbf{9 6}$ & $\mathbf{6 4}$ & $\mathbf{3 2}$ \\
\hline Fruity & 4 & 5 & 6.5 & 7 \\
Bitter & 2 & 2.5 & 2.5 & 3 \\
Pungent & 2.5 & 3.5 & 4 & 4 \\
OQI & 2.81 & 4.26 & 5.72 & 6.25 \\
\hline
\end{tabular}

Table 15. Effect of different amounts of irrigation on sensory attributes of Dolce virgin olive oils:-

\begin{tabular}{ccccc}
\hline Sensory attributes & \multicolumn{4}{c}{ Irrigation treatments (L. water / tree per hr.) } \\
\cline { 2 - 5 } & $\mathbf{1 2 0}$ & $\mathbf{9 6}$ & $\mathbf{6 4}$ & $\mathbf{3 2}$ \\
\hline Fruity & 2.5 & 3 & 3.5 & 4 \\
Bitter & 0.5 & 1 & 1 & 1.5 \\
Pungent & 0.5 & 0.5 & 1 & 1.5 \\
OQI & 1.51 & 2.2 & 3.25 & 3.43 \\
\hline
\end{tabular}

\section{Conclusion}

Physical, chemical and organoleptic characteristics of olive fruits oil improved with decreasing amount of irrigation water are given to olive trees (Coratina and Dolce vars.), also deficit irrigation water caused an increase in oleic acid, total polyphenols, O- di phenols, oxidative stability and OQI and also oil content recorded gradually increase with decreasing amounts of irrigation water. On the other hand, yield fruit / tree and promological parameters were decreased as a result reduced amount irrigation water are given to both olive tree varieties.

\section{Recommendation}

The findings show that treatment $96 \mathrm{~L}$. / tree (at rate $80 \%$ ) can be recommended for Coratina and Dolce vars.,application of this recommendation can achieve $20 \%$ saving in water and make a significant contribution to the conservation of limited water resources.

\section{References}

A.O.A.C. 2000. Official methods of analysis of the association of official analytical chemists. $17^{\text {th }}$
Edn., association of official analytical chemists, Washington, DC., USA.

A.O.A.C. 2012. Official methods of analysis of AOAC International. $19^{\text {th }} \mathrm{Ed}$. association of official analytical chemists, Gaithersburg, Maryland. U.S.A.

Alegre S.; Marsal J.; Mata M.; Arbones A. and Girona J. 2002. Regulated deficit irrigation in olive trees (Olea europea L.cv. Arbequina) for oil production. Acta Hortic 586, 259-262.

Aparicio R. and Luna G. 2002. Characterisation of monovarietal virgin olive oils. Eur. J. Lipid Sci. Technol 104, $614-627$.

Berenguer M. j.; Vossen P. M.; Grattan S.R.; Connell J. H. and Polito V.S. 2006. Tree irrigation levels for optimum chemical and sensory properties of olive oil.Hort. Sci. 41 (2): 427-432.

Bermudez , B Lopez; Sortega, A; Varela, LM; Pacheco YM; Abia, R. 2011. Oleic acid in olive oil: Fram a metabolic fram work toward a clinical perpective. Curr pharmaceud Des: 831 -843 .

Celil T.; Derya O.; Sermet O. and Ercan Y. 2009. Determination of fruit and oil characteristics of olive (Olea europea L.cv. Gemlik) in different 
irrigation and fertilization regimes. African J. of Agric. 4 (7), 649-658.

d'Andria R., Lavini A.; Morelli G.; Patumi M.; Terenziani S.; Calandrelli D.and Fragnito F. 2004. Effects of water regimes on five pickling and double aptitude olive cultivar (Olea europaea L.). J. Hort. Sci. Biotechnol. 79 (1): 18-25.

Dabbou S.; Chehab H.; Faten B.; Dabbou S.; Esposto S.; Selvaggini R.; Tatoccjo A.; Servili M.; Montedoro G. F. and Hammami M. 2010. Effect of three irrigation regimes on Arbequino olive oil produced under Tunisian growing conditions. Agric. Water Mgmt., 97 (5), 763-768.

Garcia J. M.; Cuevas M. V. and Femandez J.E. 2013. Production and oil quality in Arbequina olive (Olea europaea, L.) trees under two deficit irrigation strategies. Irrig. Sci., 31 (3), 359-370. http:// dx. Doi. Org / 10.1007 / s00271-011-031s-z.

Gomez-Rico A.; Salvador M.D.; Moriana A., Perez D.; Olmedilla N.; Ribas F. and Fregapane G. 2007. Influence of different irrigation strategies in a traditional cornicabra cv. Olive orchard on virgin olive oil composition and quality. Food Chem. 100,568 -578 .

Gomez-del-campo M. (2013): Summer deficit irrigation strategies in a hedgerow olive orchard cv. Arbequina: Effect on fruit characteristics and yield. Irrig. Sci. 31 (3), 259269. http : // dx. Doi. Org / 10.1007 / s00271011-0299-8.

Goldhamer D.A. 1999. Regulated deficit irrigation for California canning olives. Acta Hortic 474, 369-372.

Gutfinger, T. 1981. Polyphenols in olive oils. J. A.O.C. SoC. 61 (9): 966- 968.

Grattan S. R.; Berenguer M.J.; Connell J. H.; Polito V. S. and Vossen P. M. 2006. Olive oil production as influenced by different quantitaties of applied water. Agricultural water Management 85, 133-140.

Iniesta F.; Testi L.; Orgaz F. and Villalobos F. J. 2009. The effects of regulated and continuous deficit irrigation on the water use, growth and yield of olive trees. Eur. J.Agron 30, 258-265.

IOC. 2007. International Olive Council, Organoleptic assessment of virgin olive oil. 20 September French.

IOOC. 2001. Method of analysis of the International Olive Oil Council preparation of the fatty acid methyl esters from olive oil and olive pomace oil CO/T.20/DOC.

IOOC. 1990. International Olive Oil Council, Activities of cooperation technique. Olivae, 38 , 12.

Kates, N. 1972. Technique of lipidology American Elsevir Publishing Co-Inc. New york.
Kaya U; Ozturk Gungor F.; Camoglu G; Akkuzu E; Asik S. and Koseoglu O (2017) : Effect of deficit irrigation regimes on yield and fruit quality of olive trees (cv Memecik) on the Aegean Coast of Turkey.Irrig and Drain. 66:820-827.

Maria J. B; Paul M.V.; Stephen R. G.; Joseph H.C. and Vito S. P. (2006): Tree irrigation levels for optimum chemical and sensory properties of olive oil. Hort Science 41 (2): 427-432.

Mendez, E.; Sanhveza J.; Speisky II. and Valenzvela A. 1997. Comparisons oxidative stability of fish oil. J. A. O. C. SoC., 74 (3): 331- 332 .

Mohamed M. and Sallanon H. 2006. The effects of extraction methods on major fatty acid composition and antioxidant content and sensory quality virgin olive oils produced in Demeshk. J.of Agric. Sci.Soyria University.22 (1), 223-234.

Moriana A.; Orgaz F.; Pastor M. and Fereres E. (2003): Yield responses of a mature olive orchard to water deficits. J. Amer Soc. Hort Sci. 128 (3), 425-431.

Motilva M. J.; Tovar M.J.; Romer M. P. Alegre S. and Girona J. (2000): Influence of regulated deficit irrigation strategies applied to olive trees (Arbequina cultivar) on oil yield and oil composition during the fruit ripening period. J. Sci. Food Agric. 80, 2037-2043.

Mosquera, M.M.L.; Rejano N.L.; Gandul R.B.; Sanchez G.A.; and Garrido F.J. (1991): Color pigments correlation in virgin olive oil. J.A. O. C. S., 68,332-336.

Ramos A.F. and Santos F. L. (2010): Yield and olive oil characteristics of a low-density orchard (c.v Cordovil) subjected to different irrigation regimes. Agric. Water Mgmt., 97 (2), 363-373. http: // dx.doi.org / 10.1016 / j. agwat. 2009.10.008.

Ruiz-Sanchez M.C.; Domingo and Castel J.R. (2010): Review deficit irrigation in fruit trees and vines in Spain. Spanish J. of Agric. Research 8 (52), s 5-s 20.

Talozi S. and Alwaked L. (2016) : The effects of regulated deficit irrigation on the water demand and yield of olive trees. Applied Engineering in Agriculture .32 (1): 55-62.

Tognetli R.; d'Andria R.; Morelli G. and Alvino A. 2005. The effect of deficit irrigation on seasonal variations of plant water use in (Olea eurpaea L.) Plant Soil, 273 (1), 139-155. http :// dx. doi. Org / 10.1007 / s 11104-004-7244-z.

Salvador M.D.; Aranda F.; Gomez-Alonso S. and Fregapane G. 2001. Cornicabra virgin olive oil: a study of five crops seasons. Composition, quality and oxidative stability. Food chem. 74, 267-274. 
Servili M.; Esposto S.; Lodolini E. M.; Selvaggini R.; Taticchi A.; Urbani S.; Montedoro G. F.; Serravalle M. and Gucci R. (2007) : Irrigation effects on quality, phenolic composition and selected volatiles of virgin olive oil cv Leccino. J. Agric Food Chem. 55, 6609- 6618.
Snedecor GW. and Cochran GW. (1990): Statistical Methods. 7th Ed. The Iowa state Univ Press, Ames, Iowa, USA; 593 p.

Wong, M. L., Timms, R. E. and Cioh, E. M. (1988): Colorimetric determination of total tocopherols in palm oil, olein and stearin. JAOCS,65(2): 258-261.

\section{تأثير معدلات الرى المختلفة لاشجار الزيتون على انتاجية الثماروالجودة والخواص الحسية لزيت الزيتون الناتج.

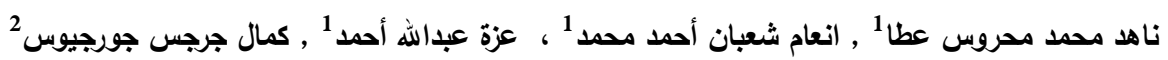

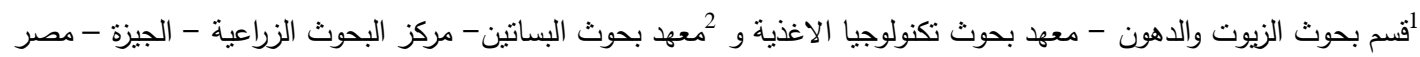

أجريت هذه التجربة فى مزرعة زيتون بوادى النطرون محافظة البحيرة مصر لدراسة تأثير معدل النقص فى كميات الرى المختلفة 96, 64, 32

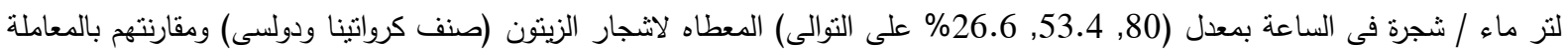

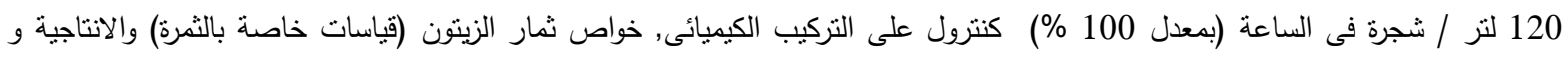

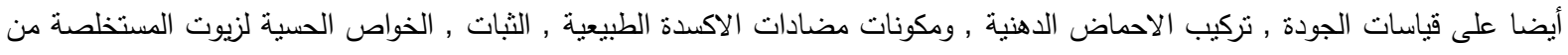

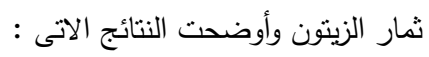
تأثرت خواص الثمار لاثتجار الزيتون صنف كرواتينا ودولسى باختلاف كميات ماء الرى حيث لوحظ تغيير معنوى لوزن ال 100 ثمرة , ووزن

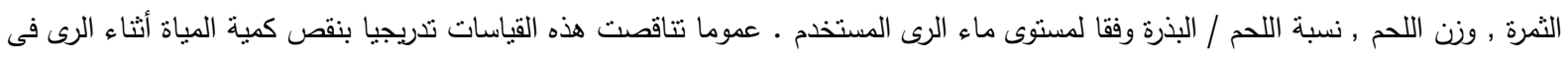

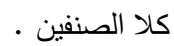
تناقصت تدريجيا قيم الحموضة والبيروكسيد والقياس فى المنطقة الفوق البنفسجية على طول موجى 232- 270 نانوميتر و الهائر بنقص كمية

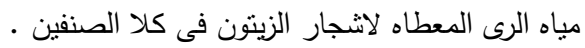

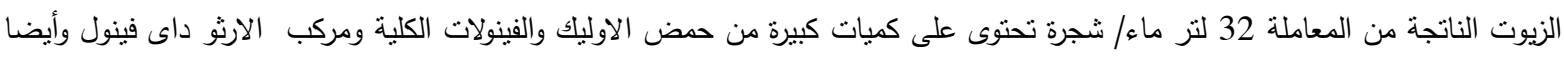

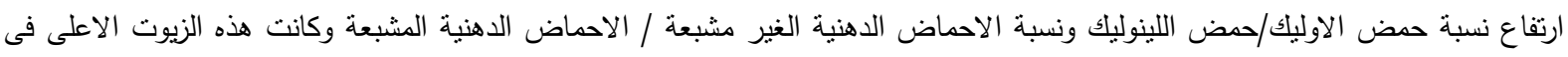
الثبات الاوكسيدى على الرغم من انخفاضهم فى مكونات التوكوفيرولات والكاروتينات والكلوروفيل مقارنة بالمعاملات الإنيات الاخرى.

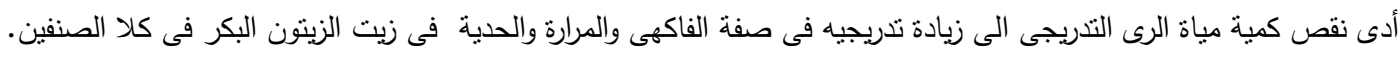

